\title{
ASSESSMENT AND FORECASTING OF BIOMASS POTENTIAL AND ENERGY DEMAND OF WONDO GENET DISTRICT, SIDAMA REGIONAL STATE, ETHIOPIA
}

\author{
Berhanu Sugebo ${ }^{1}$ \\ ${ }^{1}$ Forest products Innovation Research and Training Center P.O.BOX 2322 Addis Ababa, Ethiopia
}

\begin{abstract}
Biomass energy is one of the important alternative sources of energy because it is renewable, cheaper, readily available and environmentally friendly. In Ethiopia, the lack of access to modern energy services that are clean, efficient and environmentally sustainable is a critical limitation of economic growth and sustainable development. The main aim of the present study was to assess biomass potential and energy potential from chat,sugarcane and coffee husk in Wondo Genet District and to forecast biomass and energy potential of the District for the coming ten years. Secondary data from agricultural office of Wondo Geneet District were used as data source of yearly available biomass potential and also purposively 60 electric city user households from the District were interviewed on their amount of energy consumption per month. Biomass potential forecasting for the next ten years was done using empirical formula. In the District in 2019 the total area covered by chat, coffee plant and sugarcane was 5414 hectares and from crop production 7255.03tons per year of residue was produced.The amount of energy produced from chat waste, coffee husk and sugarcane waste was 46397.62 GJ/year. Yearly growth rate of agricultural residues of chat,sugarcane and coffee husk is $2.7 \%, 2.3 \%$ and $1.4 \%$ per year respectively and after ten years residues will be grown 9224.602 tons/year. In the year of 2019,the average energy consumption of households in the District was $6 \mathrm{KWh} /$ day and total energy consumption of households in the Distric was 2040.22152GWh/year.The energy demand for households after ten years will be grown 472.021009979GJ/year.
\end{abstract}

KEY WORDS: Biomass, Chat, coffee husk, energy

\section{INTRODUCTION}

Biomass energy is one of the important alternative sources of energy because it is renewable, cheaper, readily available and environmentally friendly (UNCTAD, 2008). Currently, several biomass technologies have been mentioned as being viable in the world. These include: electricity generation through direct combustion or gasification; briquetting; biogas generation, etc.

Per capita energy consumption of Ethiopia is very low; average energy per capita is not more than $100 \mathrm{kWh}$ per year,when $500 \mathrm{kWh}$ per year is considered the average minimum level consumption per capita for reasonable quality of life (Minster of
Water and Energy, 2013). In Ethiopia biomass accounts about $88 \%$ of the total energy consumed. In urban areas $75.3 \%$ of the residents use electricity for lighting, while rural areas kerosene $80.1 \%$ and firewood $18.5 \%$ are predominant. In rural areas electricity is not common in many villages. Access to electricity in rural areas is about $2 \%$, for a whole the country this is $10 \%$ (Erbato and Hartkopf, 2012).

Biomass energy demand is growing steadily with population growth: whereby, wood fuel is still the most important biomass fuel in Ethiopia. While, the supply base for wood fuel is shrinking, demand for wood fuel is growing rapidly. Moreover crop residues availability has increased significantly 


\title{
EPRA International Journal of Research and Development (IJRD)
}

\author{
Volume: 6 | Issue: 2 | February 2021
}

- Peer Reviewed Journal

because of increased crop production, crop production in Ethiopia has increased by $6 \%$ while agricultural residues by 3.4\% ("Ethiopian National Energy Policy," 2013).In Wondo Genet District like other parties of the country, more than $90 \%$ of population was fuel wood dependent to fulfil daily energy consumption. And also in the District, cash crop production like chat, sugarcane and pineapple increased due to expected higher economic returns and market accessibility. The expansion of the Chat in the District resulted in a $30 \%$ decline of natural forest and associated forest fragmentation in major Chat producing areas, a decline in food crop production, and soil erosion from steep land cultivation (Dessie and Kinlund, 2008). The main aim of the present study was to assess biomass potential of chat, sugarcane and coffee husk and to project energy potential and energy demend for coming ten years in the District.

\section{MATERIALS AND METHODS \\ 2. 1 Description of the Study Area}

Wondo Genet District lies at $7^{\circ} 10^{\prime} \mathrm{N}$ to $7^{\circ} 50^{\prime}$

$\mathrm{N}$ latitude and $38^{\circ} 36^{\prime} \mathrm{E}$ to $38^{\circ} 38^{\prime} \mathrm{E}$ longitude, located in the area of the Hawassa watershed in the East African rift zone, which is $260 \mathrm{~km}$ south of Addis Ababa (Fig 1). The District topography is featured by rolling upland in 1700-2600 meter above sea level (masl) with one third of the land over 2200 masl and the major part of the area is steeply $(>30 \%)$ sloped. There are three major land uses, namely forests, pastures and cultivated lands. The higher altitudes and steep slopes support natural forests and by comparison, in lower altitudes and gentle terrain, farmland is the main land use where a significant number of diverse natural on-farm trees grow. In the District two rainy seasons are characterized: a long one from July to September and a short one from February to April, leading to the annual rainfall be at $1244 \mathrm{~mm}$ and the mean annual temperature of $19^{\circ} \mathrm{C}$ (Dessie Gessesse and Kleman Johan, 2007).

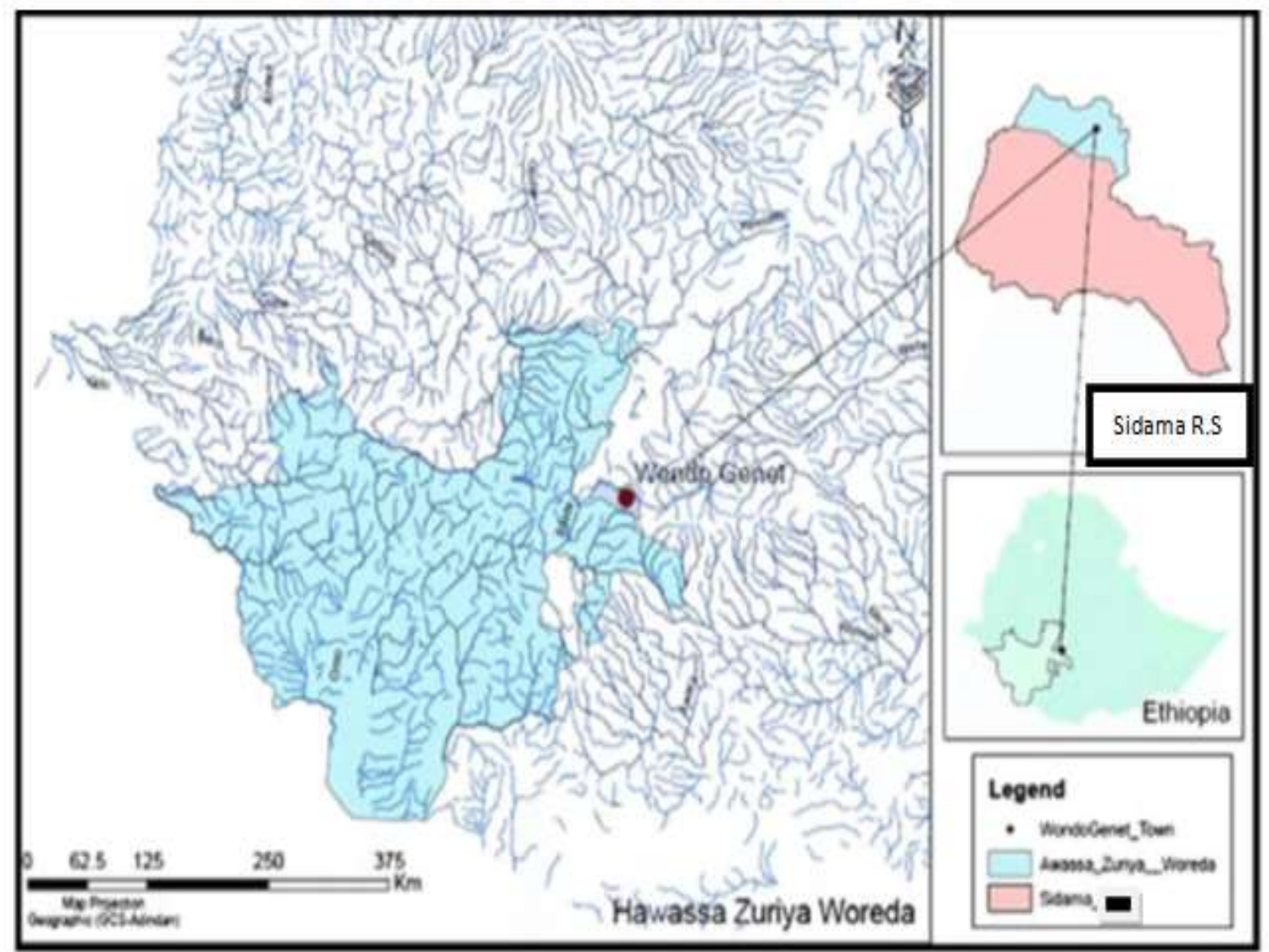

Figure 1: Map of the study area

\subsection{Source of data}

The secondary data were collected from Water Mineral and Energy office and Agricultural office of the District to deterimine agricultural crop potential in 2019 and primary data was collected on the household energy consumption. Additionally, population data of the District was obtained from Central Statistical Agency (CSA) 2013. 


\section{EPRA International Journal of Research and Development (IJRD)}

Volume: 6 | Issue: 2 | February 2021

- Peer Reviewed Journal

\subsection{Type of biomass and available potential in the District.}

According to the secondary data collected from Wondo Genet District in 2019 the most abundant biomass resources available in the area were generally divided into three biomass fractions: estimated agricultural residue (Energy crops of sugarcane, enset, chat, maize, and coffee) was 70,500 tons per year, forest biomass (forest residue): the estimated forest cover change in the District is 11,200 hectares per year and livestock waste (animal dung and slaughter wastes) is predicted to be $143,000 \mathrm{Kg}$ per year.

\subsection{Biomass Potential Projection of the District after 10 years}

To project the future biomass potential of the District after 10 years; was estimated by using the methodology suggested by (Ayamga et al., 2015). The data from the District Agricultural office and forest development office indicated that (especially crop yields) annual growth rate have not followed any clear pattern and have been fairly constant over the last decade or it depends on the erratic annual rainfall levels. For the purpose of the present study only sugarcane, coffee and chat annual growth rate was considered in order to estimate the future biomass availability after 10 years because these selected crops are the most dominated in the District. According to secondary data obtained in 2019 from District Agricultural office, annual growth rate of biomass is sugarcane $(2.3 \%)$, chat, $(2.7 \%)$ and coffee husk $(1.4 \%)$. The projection of biomass potential for the District was calculated using empirical formula suggested by (Ayamga et al., 2015).

$$
\begin{aligned}
& \mathbf{P}_{\mathbf{n}}=\mathbf{P}_{\mathrm{o}}(\mathbf{1 + r} / \mathbf{1 0 0})^{\mathrm{n}} \text {------- e.q (1). } \\
& \text { where, } \\
& \mathrm{P}_{\mathrm{n}}=\text { future biomass available, } \\
& \mathrm{P}_{0}=\text { current biomass available, } \\
& \mathrm{r}=\text { growth rate of biomass type, and } \\
& \mathrm{n}=\text { projected number of years. }
\end{aligned}
$$

\subsection{Estimation of Current and after ten years energy consumption of the District}

To estimate the District's current and future energy consumption; purposive sampling method was used. Accordingly, 60 electricity users households were selected. The energy consuming house equipments (electric cooking stove, enjera baking electric mitad, refrigator, lighting television and others) were carefully obtained by interviewing the sampled households. Finally, in the year of 2019 the District's energy consumption and after 10 years energy consumption of the district were determined by using empirical formula suggested by (Bhattacharyya and Timilsina, 2009).

\footnotetext{
$\mathrm{AEC}_{(\mathrm{kWh} / \mathrm{day} / \mathrm{hh})}=$
}

$\left(\mathrm{AP}_{(\mathrm{kW})} * \mathrm{AT}_{(\mathrm{h} / \mathrm{day})}\right) /$ House hold $(\mathrm{HH})$----e.q (2). Where,

AEC is average electricity consumption per day per household in Kilo watt hour per day (KWh/day)

AP is average power consumption per day in kilo watt $(\mathrm{KW})$

AT is average time used per day (hr/day)

$\mathrm{HH}$ is number of family in the household

To project the energy consumption after coming ten years was used the formula:

$\mathrm{Pc}=$ population no $\times$ annual energy demand growth rate $\times \mathrm{Pn} \times \mathrm{n} /$ number of households --------- e.q (3).

Where,

pc, $=$ predicted consumption per year

$\mathrm{Pn},=$ current energy consumption per year

$\mathrm{N}=$ predicted year

Ethiopian energy demand growth is $9 \%$ year (Guta and BBrner, 2015).

\subsection{Population of the District and projection after 10 years}

Based on the CSA report of 2013, Wondo Genet District has a total population of 232,899 of whom 119,010 are male and 113,889 female; 41,783 or $17.94 \%$ of its population are urban dwellers. The future population growth of Wondo Genet District was estimated by depending on the current Ethiopian population growth rate, which was taken from the Ethiopian central statistical agency (CSA) and it is calculated as follows:

$$
P_{f}=2.6 / 100 \times P_{r} \times n \text {--------------------e.q (4). }
$$

Yearly population growth rate of Ethiopia is $2.6 \%$ (source:- World bank report,2019)

$\operatorname{Pr}=$ current population and

$\mathrm{n}=$ projected number of year.

Finally, the house hold number was estimated based on current Ethiopian average persons per household (6 persons per household).

Total number of households in $2019=232899 / 6=$ 38817

Number of population will increase after ten year $=$ $2.6 / 100 * 232899 * 10=60553$

Total number of population after ten year will be $=$ $232899+60553=293452$

\subsection{Deteriming the Potential of Agricultural Residues}

Even though, the crop residues have different categories (gross residues and surplus residues), here only the surplus residues were considered since the farmers use the others for different purposes. The formula used for calculating the energy potential from crop residues was adopted from (Okello et al., 2013). Surplus amount of residue, which can be used for energy purposes, is given as: 


\section{EPRA International Journal of Research and Development (IJRD)}

$\mathrm{R}_{\mathrm{s}(\mathrm{i})}=\sum_{=1}^{n}\{[R P R i *(A i * Y i]\} * S A F i$ ----- equation ( 5 ).

Where:

$R_{s}(i)$ is the surplus residue potential of ith from $n$ number of crops (ton/year),
$\mathrm{SAF}_{\mathrm{i}}$ is surplus availability factor or surplus residue firaction of the crops,

$\mathrm{A}_{\mathrm{i}}$ is the area used for crops ith per hectare, $\mathrm{Y}_{\mathrm{i}}$ is yield of the crop ith (ton/area), $\mathrm{RPR}_{\mathrm{i}}$ is residue to product

Table 1: Potential of Biomass to Energy Conversion

\begin{tabular}{lccc}
\hline \multicolumn{1}{c}{ Types of crops } & $\begin{array}{c}\text { Residue to product } \\
\text { ratio (RPR) }\end{array}$ & $\begin{array}{c}\text { Surplus availability } \\
\text { factor (SAF) }\end{array}$ & $\begin{array}{c}\text { Lower heating value } \\
\text { (LHV) MJ/Kg }\end{array}$ \\
\hline Sugarcane bagasse & 0.29 & 1 & 13 \\
Sugarcane top \& leaves & 0.32 & 0.8 & 15.8 \\
Coffee husk & 21 & 1 & 12.8 \\
Chat & 0.35 & 0.9 & 20 \\
\hline
\end{tabular}

Source :- (Gabisa and Gheewala, 2018)

\subsection{Estimation of Energy Potential from Biomass}

Bio-energy crop residue potential from biomass was estimated method use (Okello et al., 2013).

$\mathrm{E}_{\mathrm{ACR}}=\sum_{=1}^{n} R s(i) * L H V i$------------- e.q (6).

Where:

$\mathrm{Rs}_{(\mathrm{i})}$ is the surplus residue potential of crop ith from $n$ number of crops (ton/year);

$\mathrm{LHV}_{\mathrm{i}}$ is the lower heating value of crop ith from $\mathrm{n}$ number of crops $(\mathrm{MJ} / \mathrm{kg})$

\subsection{Biomass to Energy Conversion}

The estimation of potentially producible energy requires the approach of how much energy is stored in the biomass. Once having this value, the electrical energy that can be produced is obtained applying the efficiency of the conversion system to the total amount of energy released from the available biomass.

Potentially generable Electricity estimation $(\mathrm{GW})=$ total biomass energy potential $(\mathrm{GW}) \times$ energy conversion efficiency $(\eta)$ (in this case efficiency $=$ 37\% (Sharma et al., 2014).(Sharma et al., 2014)

\subsection{Projection of the District's Biomass} Energy Potential after Ten Years

Electricity generation from biomass after ten years was calculated by the formula as follows
Eg $=$ Ec $\times$ efficiency $(\eta) \times$ projected year (in this case 10 years) ------------------ e.q (7).

Where,

Eg $=$ energy generated after ten years

$\mathrm{Ec}=$ current electricity generated from biomass

$\eta=$ Energy conversion efficiency given which was $37 \%$ (Sharma et al., 2014).

\subsection{Projection of the District energy consumption after ten years}

Annual population growth rate of Ethiopia is 2.6\% (World bank 2019) and energy demand growth rate is 9\% per year annum (Guta and BBrner, 2015) .

The collected data was analysed by using Microsoft excel software.

\section{RESULT AND DISCUSSION}

\subsection{Available biomass potential in the District}

Based on data collected from Wondo Genet District agricultural development office in 2019 the potential of biomass and biomass energy potential are given in Table $2 \& 3$.

Table 2: Potential of biomass in the District

\begin{tabular}{lcccc}
\hline Crop type & $\begin{array}{c}\text { Production } \\
\text { Year }\end{array}$ & Area covered (ha) & $\begin{array}{c}\text { Average crop } \\
\text { production (ton/year) }\end{array}$ & $\begin{array}{c}\text { Average yield } \\
\text { (ton/ha) }\end{array}$ \\
\hline Sugarcane & 2019 & 441 & 1543.5 & 3.5 \\
Coffee & 2019 & 685 & 68.5 & 0.1 \\
Chat & 2019 & 4288 & 17152 & 4 \\
Total & & 5414 & 18764 & 7.6 \\
\hline
\end{tabular}




\section{EPRA International Journal of Research and Development (IJRD)}

Volume: 6 | Issue: 2 | February 2021

- Peer Reviewed Journal

Table 3: Biomass residue and energy potential of the District

\begin{tabular}{|c|c|c|c|c|c|c|c|c|c|}
\hline $\begin{array}{l}\text { Type of } \\
\text { crop }\end{array}$ & $\begin{array}{l}\text { Type of } \\
\text { residue }\end{array}$ & $\begin{array}{l}\text { Producti } \\
\text { on/ton/y } \\
\text { ear }\end{array}$ & RPR & SAF & $\begin{array}{l}\text { Surplus } \\
\text { residue } \\
\text { potential } \\
\text { (ton) }\end{array}$ & $\begin{array}{c}\text { Total } \\
\text { residue } \\
\text { (ton) }\end{array}$ & $\begin{array}{c}\mathrm{LHV}(\mathrm{MJ} / \mathrm{K} \\
\mathrm{g})\end{array}$ & $\begin{array}{c}\text { Efficie } \\
\text { ncy }\end{array}$ & $\begin{array}{l}\text { energy } \\
\text { potential } \\
\text { (GJ/year) }\end{array}$ \\
\hline coffee & $\begin{array}{l}\text { coffee } \\
\text { husk }\end{array}$ & 68.5 & 21 & 1 & 1438.5 & 1438.5 & 12.8 & 0.35 & 6444.48 \\
\hline chat & $\begin{array}{c}\text { chat } \\
\text { waste }\end{array}$ & 17152 & 0.35 & 0.9 & 5402.88 & 5402.88 & 20 & 0.35 & 37820.16 \\
\hline sugarcan & bagasse & 543.5 & 0.29 & 1 & 157.65 & 157.65 & 13 & 0.35 & 717.3 \\
\hline $\mathrm{e}$ & $\begin{array}{l}\text { tops \& } \\
\text { leaves }\end{array}$ & 1000 & 0.32 & 0.8 & 256 & 256 & 15.8 & 0.35 & 1415.68 \\
\hline Total & & 18764 & & & 7255.03 & 7255.03 & & 0.35 & 46397.62 \\
\hline
\end{tabular}

3.2 Biomass energy potential and energy consumption of households By using the obtained energy potential and recommended efficiency (efficiency given 35\%) it was able to calculate energy potential from each crop and the result is given in Table 4 .

Table 4: Biomass energy potential and energy consumption of households

\begin{tabular}{|c|c|c|c|c|}
\hline Crop type & $\begin{array}{l}\text { Estimated energy potential } \\
\text { (GJ/year) }\end{array}$ & $\begin{array}{l}\text { Total } \\
\text { number of } \\
\text { household }\end{array}$ & $\begin{array}{l}\text { Average energy } \\
\text { consumption } \\
\text { (Kwh/Day/HH) }\end{array}$ & $\begin{array}{l}\text { Total household } \\
\text { energy consumption( } \\
\text { GWh/ year }\end{array}$ \\
\hline Chat & 37820.16 & & & \\
\hline Coffee & 6444.48 & 38817 & 6 & 2040.22152 \\
\hline Sugarcane & 2132.98 & & & \\
\hline Total & 46397.62 & & & \\
\hline
\end{tabular}

Table 5:Projected biomass and energy potential after ten years

\begin{tabular}{|c|c|c|c|c|c|c|}
\hline Crop type & $\begin{array}{c}\text { Biomass } \\
\text { type }\end{array}$ & $\begin{array}{c}\text { Current } \\
\text { biomass } \\
\text { available } \\
\text { ton/year }\end{array}$ & $\begin{array}{c}\text { Projected } \\
\text { biomass ton/ } \\
\text { year }\end{array}$ & $\begin{array}{c}\text { Projected } \\
\text { energy } \\
\text { conversion } \\
\text { efficiency }\end{array}$ & LHV(MJ/Kg & $\begin{array}{c}\text { Projected energy } \\
\text { generation after } \\
\text { ten years } \\
\text { (GJ/year) }\end{array}$ \\
\hline Chat & & 5402.88 & 7052.28 & 0.37 & 20 & 52186.87 \\
\hline Coffee husk & & 1438.5 & 1653.063 & 0.37 & 12.8 & 7828.90637 \\
\hline \multirow[t]{3}{*}{ Sugarcane } & $\begin{array}{l}\text { tops } \\
\text { \&leaves }\end{array}$ & 256 & 321.36 & 0.37 & 15.8 & 1878.67056 \\
\hline & bagasse & 157.65 & 197.902 & 0.37 & 13 & 951.9086 \\
\hline & Total & 7255.03 & 9224.602 & & & 62846.355 \\
\hline
\end{tabular}

Table 6: Energy demand projection after ten years

\begin{tabular}{cccc}
\hline $\begin{array}{c}\text { Current } \\
\text { population }\end{array}$ & $\begin{array}{c}\text { Projected } \\
\text { population }\end{array}$ & $\begin{array}{c}\text { Current total energy } \\
\text { consumption } \\
\text { GWh/year }\end{array}$ & $\begin{array}{c}\text { Projected energy consumption } \\
\text { after ten years (GWh/year) }\end{array}$ \\
\hline 232899 & 293452 & 2040.22152 & 472.021009979 \\
\hline
\end{tabular}

Even though, residue to product ratio of chat is low, Surplus residue produced from chat in the District was very high in case of chat planted area coverage percentage in District is very high (Dessie and Kinlund, 2008). The lowest residue potential was obtained from sugarcane with low production coverage area. The energy from chat,coffee husk and sugarcane waste in Wondo Genet District was 46397.62 GJ/year. Chat residue had high energy potential with $37820.16 \mathrm{GJ} / \mathrm{year}$ and sugarcane residues was low in area and had lowest energy potential among chat residue and coffee husk in 


\section{EPRA International Journal of Research and Development (IJRD)}

Volume: 6 | Issue: 2 | February 2021

2019.The overall energy potential of the District was $46397.62 \mathrm{GJ} /$ year, and total energy consumption in one year for different household utilities was 2040.221520 GWh/year. This indicated that; the available biomass potential of the District could substitute the energy demand of the area.

\section{CONCLUSION}

Based on the present study and avaliable data,Wondo Genet District had high potential chat waste and coffee husk and low potentaial of sugarcane biomass. Conversion of available biomass to to energy could substitute energy demand of both present and after coming ten years of the District.

\section{REFERENCES}

1. Ayamga, E.A., Kemausuor, F., Addo, A., 2015. Technical analysis of crop residue biomass energy in an agricultural region of Ghana. Resour. Conserv. Recycl. 96, 51-60.

2. Dessie, G., Kinlund, P., 2008. Khat expansion and forest decline in wondo genet, ethiopia. Geogr. Ann. Ser. B Hum. Geogr. 90, 187-203.

3. Dessie Gessesse, Kleman Johan, 2007. Pattern and Magnitude of Deforestation in the South Central Rift Valley Region of Ethiopia. Int. Mt. Soc. 27, 162-168.

4. Erbato, T.T., Hartkopf, T., 2012. Smarter Micro Grid for Energy Solution to Rural Ethiopia, in: Proceedings of the 2012 IEEE PES Innovative Smart Grid Technologies, ISGT '12. IEEE Computer Society, Washington, DC, USA, pp. 17.

5. Gabisa, E.W., Gheewala, S.H., 2018. Potential of bio-energy production in Ethiopia based on available biomass residues. Biomass Bioenergy 111, 77-87.

6. Guta, D.D., BBrner, J., 2015. Energy Security, Uncertainty, and Energy Resource Use Option in Ethiopia: A Sector Modelling Approach. SSRN Electron. J. Policy No. 201, 1-39.

7. Minster of Water and Energy, 2013. Ethiopian national energy policy.

8. Okello, C., Pindozzi, S., Faugno, S., Boccia, L., 2013. Bioenergy potential of agricultural and forest residues in Uganda. Biomass Bioenergy 56, 515-525.

9. Sharma, S., Meena, R., Sharma, A., Goyal, P. kumar, 2014. Biomass Conversion Technologies for Renewable Energy and Fuels: A Review Note. IOSR J. Mech. Civ. Eng. 11, 28-35.

10. UNCTAD (Ed.), 2008. Commodity prices, capital flows and the financing of investment, Trade and development report. United Nations, New York, $N Y$. 